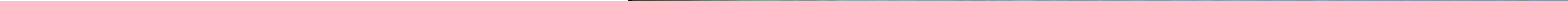




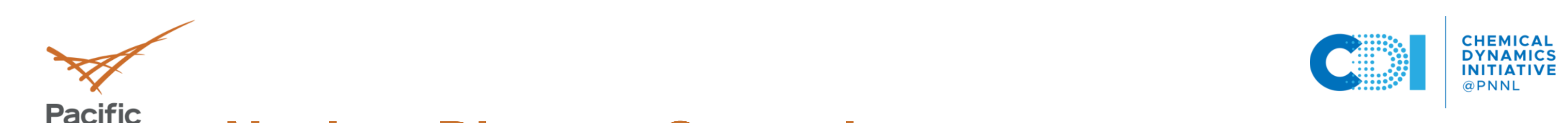

Pacific

Narthnest Nuclear Disaster Scenario

- $131 \mathrm{I}$ is released during nuclear accidents

- Generated from ${ }^{235} \mathrm{U}$ fission

- $\beta^{-}$emitter with 8 days of half-life which poses significant danger of thyroid cancer (public health concern)

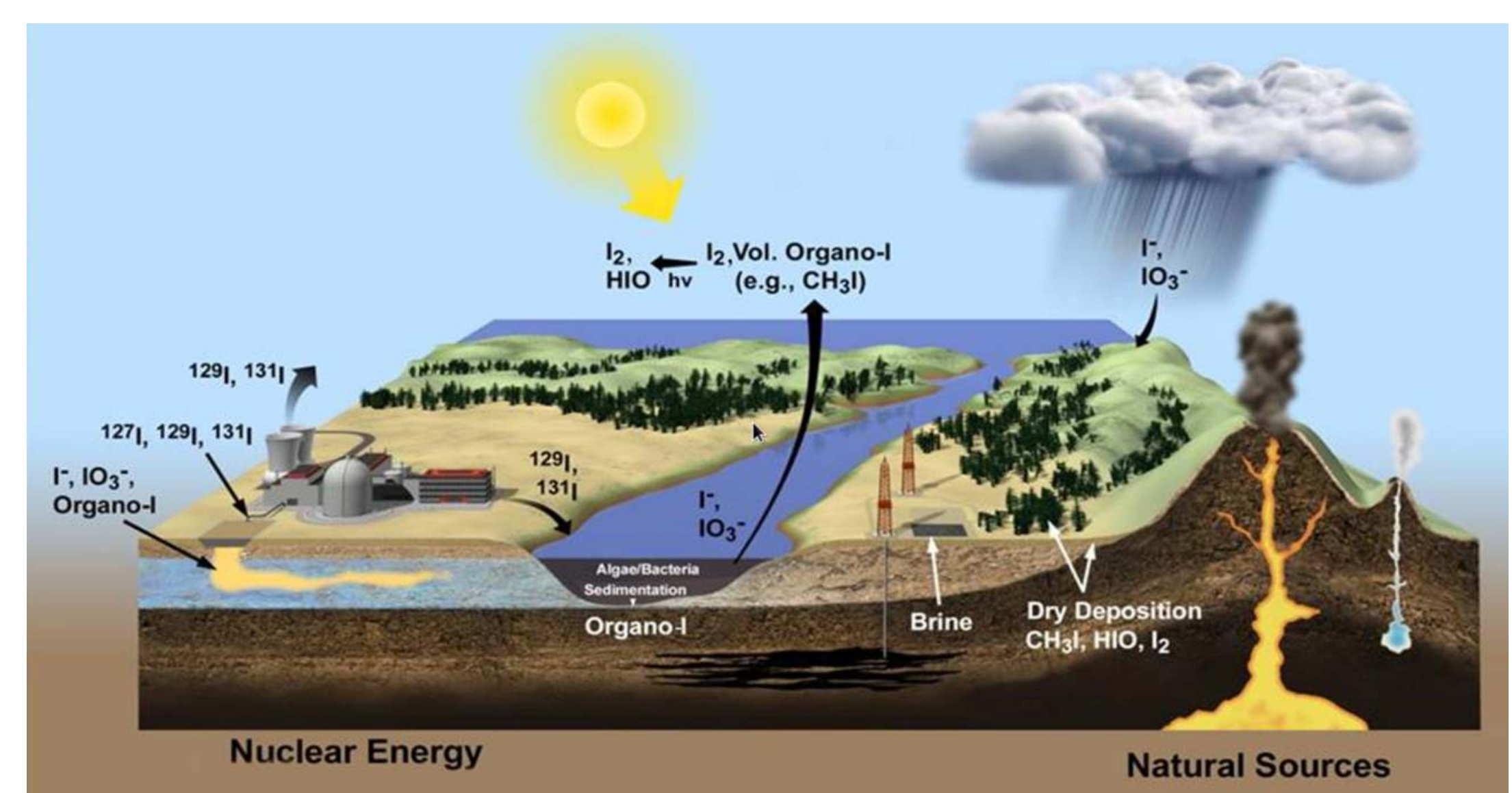

From M. J. Truex, et al. PNNL-24709 rev. 2, (2017) 
Pacific

Northwest

Nuclear Disaster Scenario - ${ }^{131}$ | Mitigation

Mitigate ${ }^{131} \mathrm{I}$ release into the atmosphere

- Thought to be released as $\mathrm{I}_{2}, \mathrm{CH}_{3} \mathrm{I}, \mathrm{HI}$, and/or $\mathrm{HOI}$ [1]

- Speciation of iodine is unclear

- Usually trapped with a sorbent such as activated carbon or metal-organic frameworks

- Trapped ${ }^{131}$ I reduce risk for human contamination and incorporation

$\square$ Goal: model the consequences of ${ }^{131}$ | radioactive decay in molecules

- Investigated of several radioiodine-bound species: $\mathrm{I}_{2}, \mathrm{CH}_{3} \mathrm{I}, \mathrm{HI}, \mathrm{HOI}, \mathrm{HIO}_{2}$, and $\mathrm{HIO}_{3}$

- Used ab initio molecular dynamic simulations to determine threshold energy required to break bonds in molecules in gas phase and adsorbed on graphite (surrogate for activated carbon) 
Pacific

Northwest

Processes Involved in ${ }^{131}$ | Beta-Decay

1. Transmutation $\left({ }^{131} \mathbf{I} \rightarrow{ }^{131} \mathrm{Xe}\right)$

2. Emission of beta-particle (ionization: ${ }^{131} \mathbf{I} \rightarrow{ }^{131} \mathbf{X e}^{+}$)

3. ${ }^{131} \mathrm{Xe}^{+}$daughter recoil (up to $\sim 6 \mathrm{eV}$ )
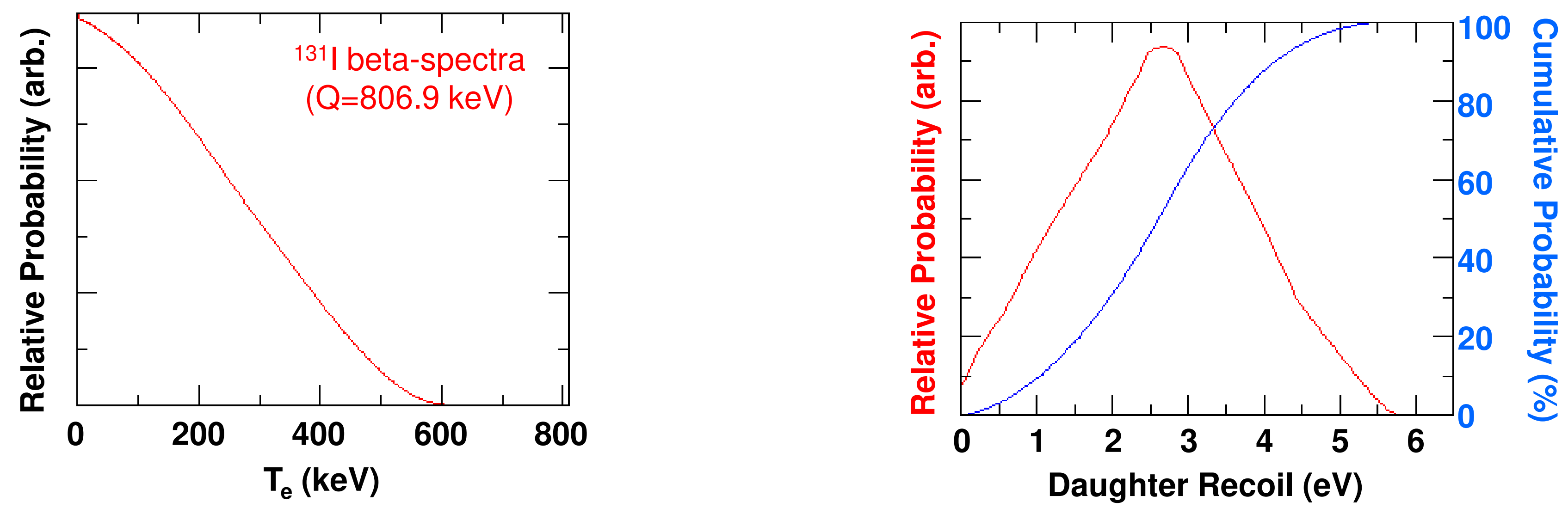
Pacific

Northwest

Consequences of Radiolytic Transmutation

Gas phase

- Transmutation in $\mathrm{I}_{2}$

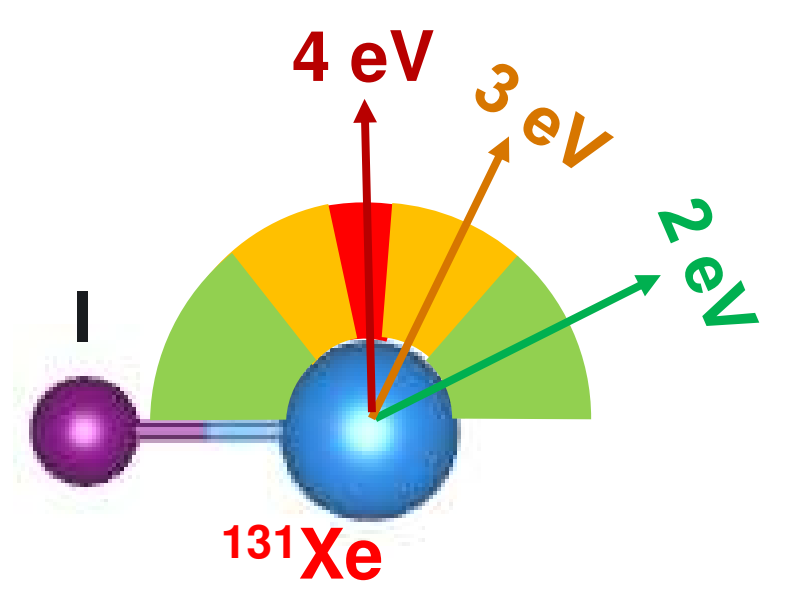

- Transmutation in $\mathrm{CH}_{3} \mathrm{I}$

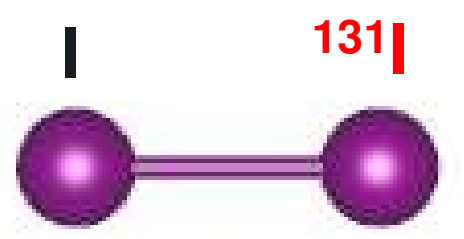

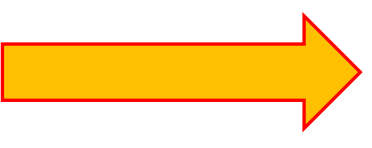

Radioactive decay

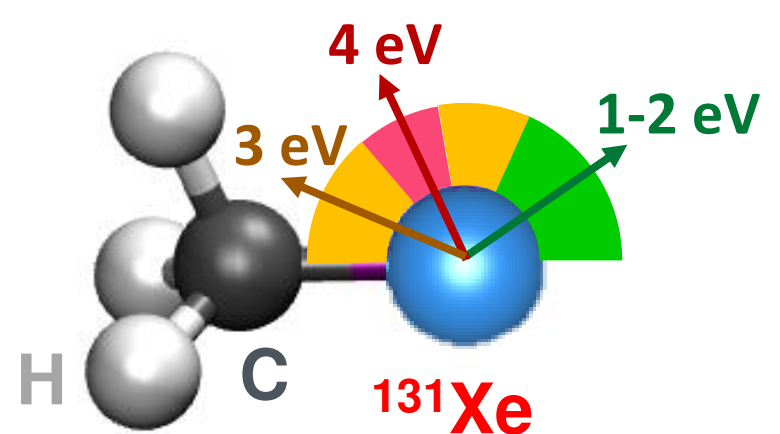

Radioactive $\mathrm{I}_{2}$ molecule

| 131|

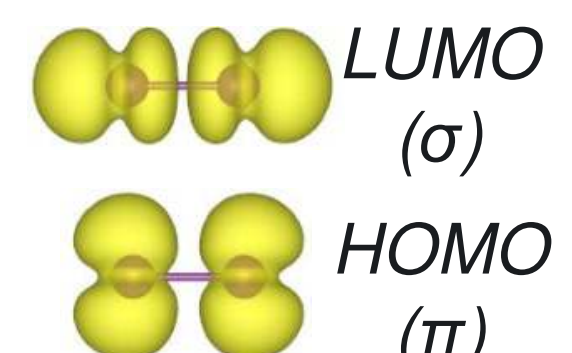

Radiogenic [IXe $]^{+}$ molecular ion

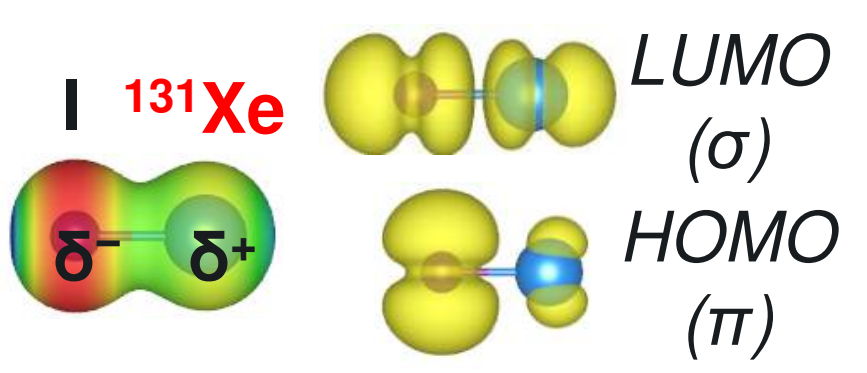

$>$ Fragmentation doesn't occur for $\left[\mathrm{CH}_{3} \mathrm{Xe}\right]^{+}$

$>$ Fragmentation does occur for doubly ionized $\left[\mathrm{CH}_{3} \mathrm{Xe}\right]^{++}$

$>$ Depending on ${ }^{131}$ Xe recoil direction bond breaking occurs for 1-4 eV of kinetic energy

$>$ Depending on ${ }^{131} \mathrm{Xe}$ recoil direction bond breaking occurs for 2-4 eV of kinetic energy 


\section{Consequences of Radiolytic Transmutation}

Gas phase

- Simulations of recoil in $\mathrm{HI}$ and $\mathrm{HIO}$ found not fragmentations for $6 \mathrm{eV}$ recoil in any directions

- Transmutation in $\mathrm{HIO}_{2}$

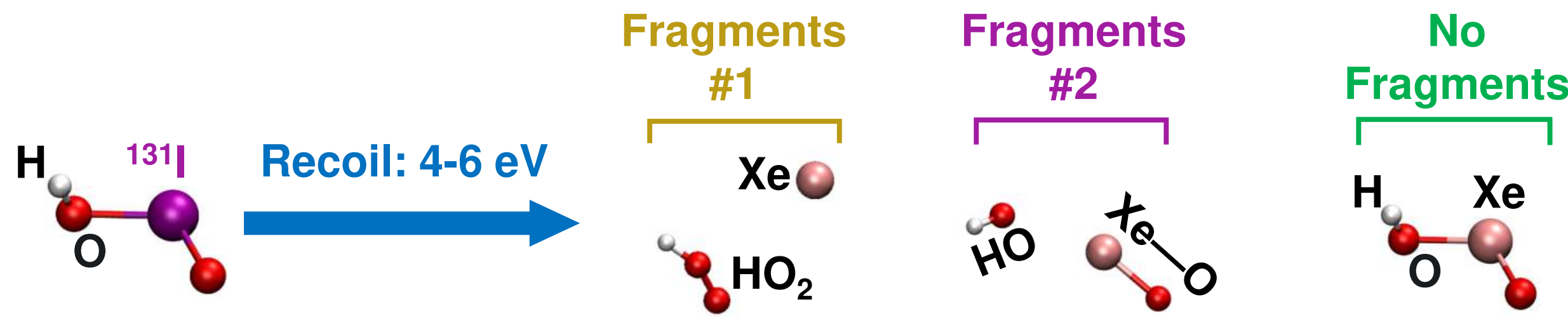

- Transmutation in $\mathrm{HIO}_{3}$
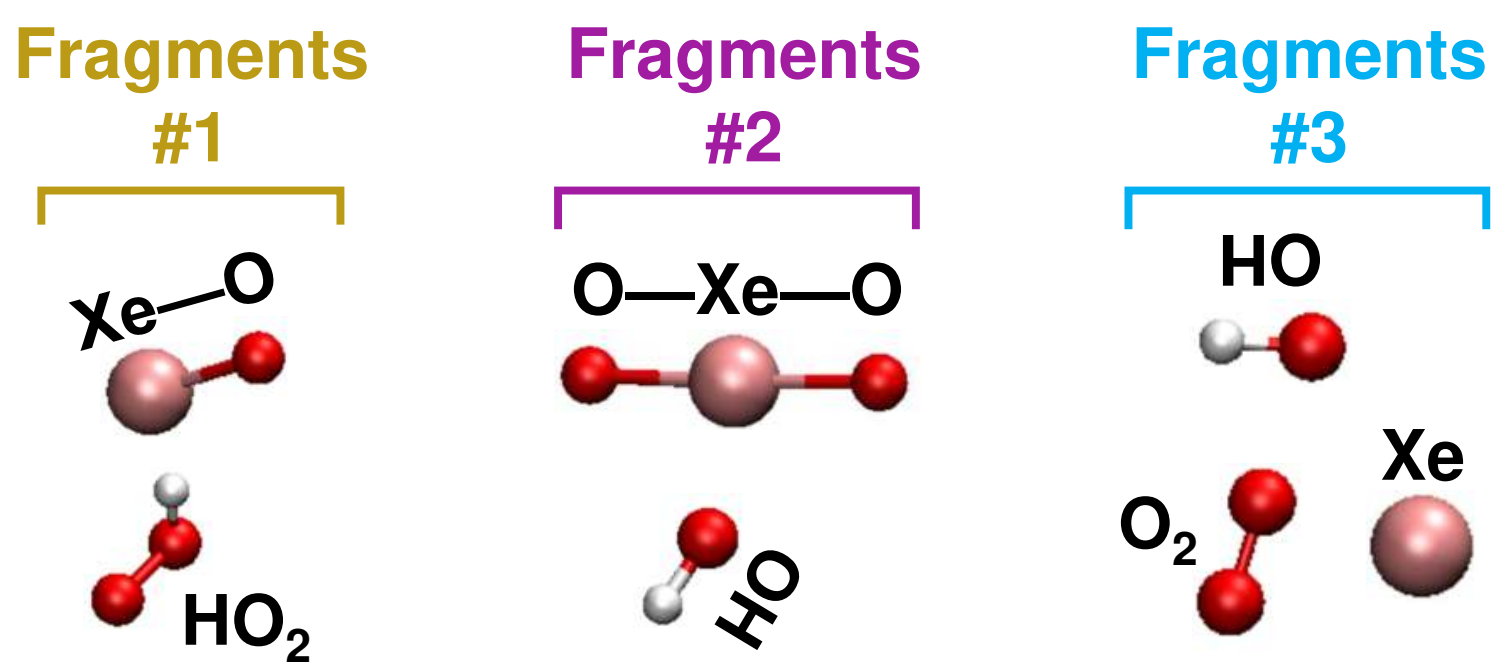

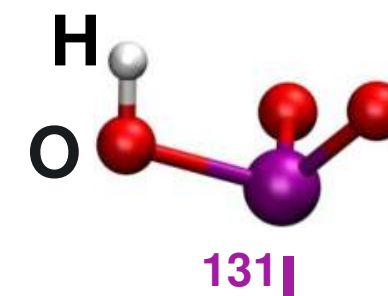

Recoil: 5-6 eV 


\section{ry \\ Pacific \\ Northwest \\ Consequences of Radiolytic Transmutation

Adsorbed on graphite

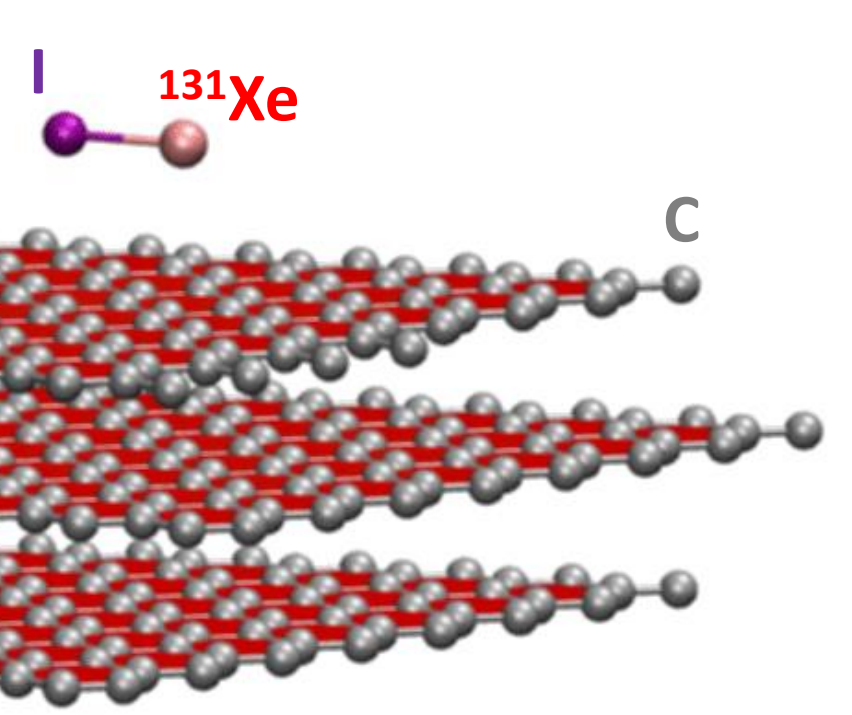

${ }^{131} \mathrm{Xe}$ recoil of $4 \mathrm{eV}$ toward graphite surface

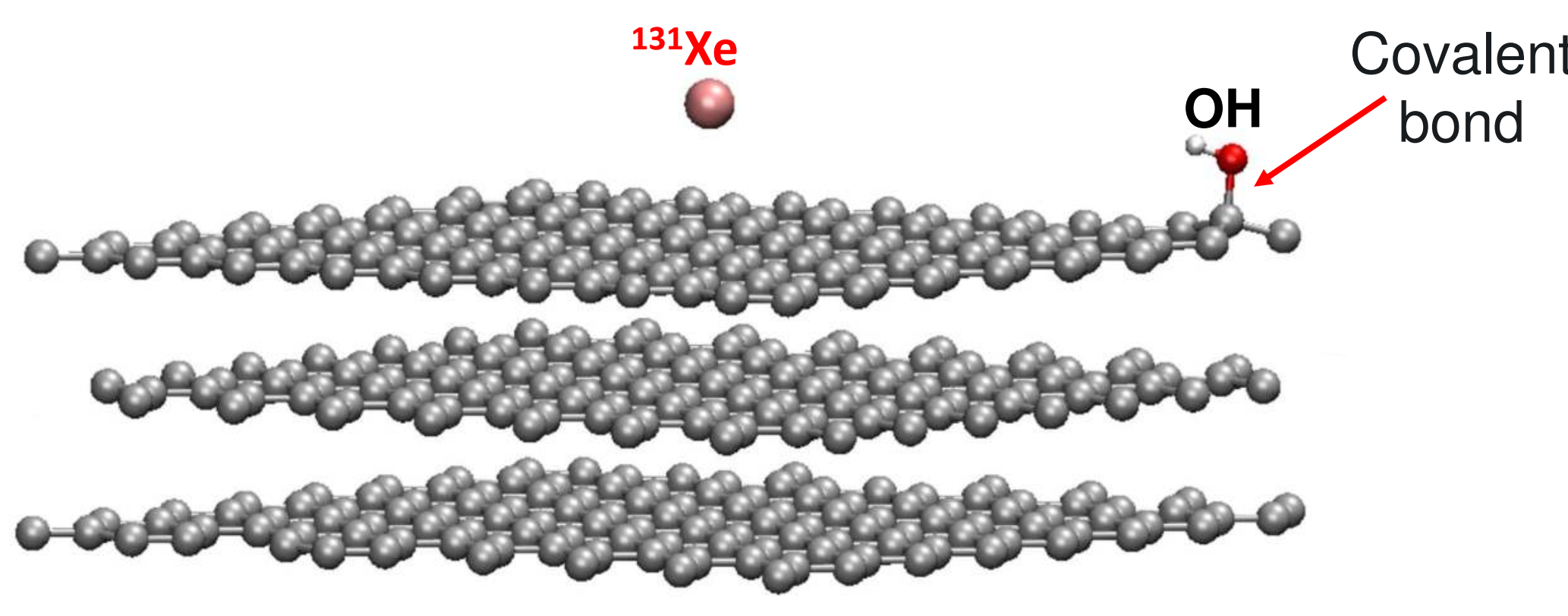

End-products from transmutation in HIO

$>$ All molecules are easier to fragment on graphite surface compared to gas phase (recoil energy $<1 \mathrm{eV}$ )

> Due to distant interactions with graphite, I and Xe fragments are likely to freely diffuse on surface (or desorb)

> Molecular fragmentations involving $\mathrm{OH} \cdot$ and $\mathrm{CH}_{3}$. radicals from dissociation of $\mathrm{XeHO}, \mathrm{XeHO}_{2}, \mathrm{XeHO}_{3}$, and $\mathrm{XeCH}_{3}$ have the possibility to form covalent bond with substrate

> Overtime, potential to reduce the number of adsorption sites available 
Pacific

Northwest

Consequences of Radiolytic Transmutation

\section{$\square$ Bader charges}

\begin{tabular}{|c|c|c|c|}
\hline \multirow{2}{*}{ Species } & \multirow{2}{*}{ Products } & \multicolumn{2}{|r|}{$\delta q^{*}(e-)$} \\
\hline & & Gas phase & Surface \\
\hline $\mathrm{I}_{2}$ & $\begin{array}{c}\mathrm{Xe} \\
\mathrm{I}\end{array}$ & $\begin{array}{l}0.36 \\
0.64\end{array}$ & $\begin{array}{l}0.01 \\
-0.36 \\
(1.35 \text { in substrate) }\end{array}$ \\
\hline $\mathrm{HI}$ & $\begin{array}{c}\mathrm{Xe} \\
\mathrm{H}\end{array}$ & $\begin{array}{l}0.75 \\
0.25\end{array}$ & $\begin{array}{l}0.01 \\
0.01 \\
(0.98 \text { in substrate) }\end{array}$ \\
\hline $\mathrm{HIO}$ & $\begin{array}{l}\mathrm{Xe} \\
\mathrm{OH}\end{array}$ & $\begin{array}{c}1.07 \\
-0.07\end{array}$ & $\begin{array}{l}0.01 \\
-0.42 \\
(1.41 \text { in substrate) }\end{array}$ \\
\hline \multirow{2}{*}{$\mathrm{HIO}_{2}$} & $\begin{array}{c}\mathrm{XeO} \\
\mathrm{OH}\end{array}$ & $\begin{array}{l}0.76 \\
0.24\end{array}$ & $\begin{array}{l}-0.01 \\
-0.45 \\
(1.46 \text { in substrate) }\end{array}$ \\
\hline & $\begin{array}{c}\mathrm{Xe} \\
\mathrm{HO}_{2}\end{array}$ & $\begin{array}{l}0.43 \\
0.57\end{array}$ & $\begin{array}{l}0.01 \\
-0.06 \\
(1.05 \text { in substrate })\end{array}$ \\
\hline
\end{tabular}

*Based on charges: $\mathrm{H}(1 \mathrm{e}-), \mathrm{Xe}(8 \mathrm{e}-), \mathrm{I}(7 \mathrm{e}-)$,

$\mathrm{O}(6 \mathrm{e}-), \mathrm{C}(4 \mathrm{e}-) . \delta>0$ : less e-. $\delta<0$ : more e-.

\begin{tabular}{|c|c|c|c|}
\hline \multirow{2}{*}{ Species } & \multirow{2}{*}{ Products } & \multicolumn{2}{|c|}{$\delta q^{\star}(e-)$} \\
\hline & & Gas phase & Surface \\
\hline \multirow{3}{*}{$\mathrm{HIO}_{3}$} & $\begin{array}{c}\mathrm{XeO}_{2} \\
\mathrm{OH}\end{array}$ & $\begin{array}{l}0.76 \\
0.24\end{array}$ & $\begin{array}{l}-0.41 \\
-0.41 \\
(1.82 \text { in substrate) }\end{array}$ \\
\hline & $\begin{array}{l}\mathrm{Xe} \\
\mathrm{O}_{2} \\
\mathrm{OH}\end{array}$ & $\begin{array}{l}0.34 \\
0.47 \\
0.19\end{array}$ & $\begin{array}{l}0.01 \\
-0.03 \\
-0.45 \\
(1.47 \text { in substrate) }\end{array}$ \\
\hline & $\begin{array}{l}\mathrm{XeO} \\
\mathrm{HO}_{2}\end{array}$ & $\begin{array}{l}0.59 \\
0.41\end{array}$ & $\begin{array}{l}-0.02 \\
-0.02 \\
(1.04 \text { in substrate) }\end{array}$ \\
\hline \multirow{2}{*}{$\mathrm{CH}_{3} \mathrm{I}$} & $\begin{array}{l}\mathrm{Xe} \\
\mathrm{CH}_{3}\end{array}$ & $\begin{array}{l}0.57 \\
0.43\end{array}$ & $\begin{array}{l}0.00 \\
0.03 \\
(0.97 \text { in substrate) }\end{array}$ \\
\hline & $\begin{array}{l}\mathrm{Xe} \\
\mathrm{CH}_{3}\end{array}$ & $\begin{array}{l}1.00 \\
1.00\end{array}$ & $\begin{array}{l}0.01 \\
0.02 \\
\text { (1.98 in substrate) }\end{array}$ \\
\hline
\end{tabular}


Pacific Northwest

\section{Consequences of Radiolytic Transmutation}

\section{$\square$ Fragmentation energetics}

\begin{tabular}{|c|c|c|c|}
\hline Species & Products & $\begin{array}{c}\text { Gas phase } \\
(\mathrm{eV})\end{array}$ & $\begin{array}{c}\text { Surface } \\
(\mathrm{eV})\end{array}$ \\
\hline $\mathrm{I}_{2}$ & $X e+1$ & 0.48 & -1.16 \\
\hline $\mathrm{HI}$ & $\mathrm{Xe}+\mathrm{H}$ & No Frag. & -1.38 \\
\hline $\mathrm{HIO}$ & $\mathrm{Xe}+\mathrm{OH}$ & No Frag. & -1.82 \\
\hline \multirow{2}{*}{$\mathrm{HIO}_{2}$} & $\mathrm{XeO}+\mathrm{OH}$ & 1.17 & -1.52 \\
\hline & $\mathrm{Xe}+\mathrm{HO}_{2}$ & -2.73 & -4.45 \\
\hline \multirow{3}{*}{$\mathrm{HIO}_{3}$} & $\mathrm{XeO}+\mathrm{HO}_{2}$ & -2.54 & -3.82 \\
\hline & $\mathrm{XeO}_{2}+\mathrm{OH}$ & 0.71 & -2.19 \\
\hline & $\mathrm{Xe}+\mathrm{O}_{2}+\mathrm{OH}$ & -1.55 & -5.72 \\
\hline \multirow{2}{*}{$\mathrm{CH}_{3} \mathrm{I}$} & $\mathrm{Xe}+\mathrm{CH}_{3}$ & 1.44 & -1.80 \\
\hline & {$\left[\mathrm{Xe}+\mathrm{CH}_{3}\right]^{+}$} & -2.17 & -1.13 \\
\hline
\end{tabular}

- Product fragments formed at the graphite surface are more favorable than in gas phase. This suggests that the fragments are very reactive in gas phase.

- There is a thermodynamic driving force favoring the formation of $\mathrm{HO}_{2}$ either in gas phase or adsorbed on graphite.

- For $\mathrm{HIO}_{3}$, a reaction competitive to the production of $\mathrm{HO}_{2}$ could involve the formation of $\mathrm{O}_{2}$. 
Radioiodine transmutation has the potential to fragment molecules

- AIMD simulations can identify the possible types of fragments

Gas phase molecular species are harder to fragment

- $\mathrm{HIO}_{\mathrm{x}}$ recoil $>4 \mathrm{eV}$

- $\mathrm{I}_{2}$ is the easiest to fragment (recoil $>2 \mathrm{eV}$ )

- The fragmentation of Methyl-lodine $\left(\mathrm{CH}_{3} \mathrm{l}\right)$ happens only when additional ionizations occur

- Gas phase results can provide useful information for atmospheric measurements

- Identified fragments can offer new chemical routes to consider in chemical kinetic models

Graphite surface facilitates molecular fragmentation

- Recoils less than $1 \mathrm{eV}$ are sufficient to break bonds

- The positive charge of the molecule is delocalized in the substrate, facilitating bond breaking

$\square$ Production of reactive fragments at surface can affect adsorption capabilities of sorbents

- $\mathrm{OH}$ and $\mathrm{CH}_{3}$ molecular fragments can form covalent bonds with the substrate 


\section{Acknowledgments}

- Financial Support:

Chemical Dynamics Initiative (CDI) at Pacific Northwest National Laboratory (PNNL)

CHEMICAL

DYNAMICS

DPNAL
- Computational Resources:

Constance cluster at PNNL

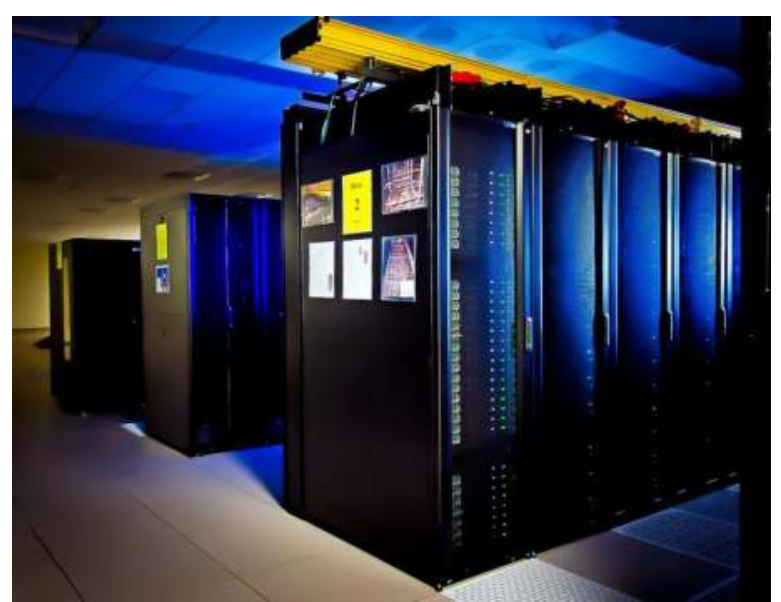


$\checkmark f$

Pacific

Northwest

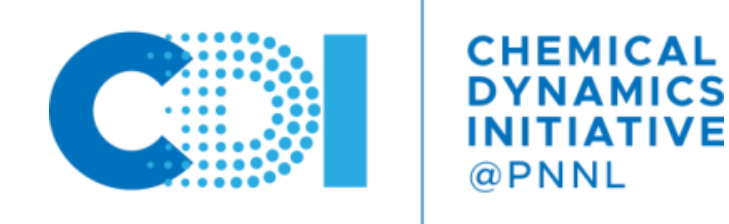

Thank you

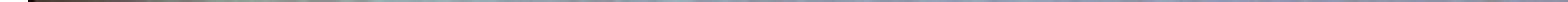

